\title{
APLIKASI WEB SISTEM INFORMASI SUNGAI DAN PANTAI (SISPA) UNTUK PENGELOLAAN SUMBERDAYA AIR
}

\author{
WEB APPLICATION INFORMATION SYSTEMS AND RIVER BEACH (SISPA) FOR WATER RESOURCE \\ MANAGEMENT
}

\author{
Heru Dwi Wahjono, B.Eng, M.Kom. \\ Pusat Teknologi Lingkungan, BPPT
}

\begin{abstract}
Abstrak
Kegiatan pembangunan selama ini telah mengeksploitasi sumber daya air (SDA) secara besar-besaran. Setiap tahunnya jumlah DAS kritis semakin bertambah seiring dengan semakin menurunnya kualitas lingkungan. Pengelolaan sumber daya air yang baik selalu terus diupayakan oleh pemerintah untuk mengurangi dampak negatif dari pencemaran lingkungan ini. Salah satunya adalah dengan membangun sebuah Sistem Informasi Sungai dan Pantai Berbasis Web yang dapat digunakan untuk mengetahui kondisi sumber daya air di suatu wilayah sungai, sehingga status potensi dan mutu air dapat dipantau setiap saat baik oleh pemerintah daerah atau pun masyarakat luas dan lembaga sosial masyarakat lainnya. Sistem linformasi Sungai dan Pantai Berbasis Web dapat diwujudkan dengan melakukan pengelolaan data sumberdaya air suatu wilayah sungai secara terstruktur melalui pengembangan Database Sumber Daya Air (DBSDA). Sistem Informasi Sungai dan Pantai (SISPA) Berbasis Web ini dikembangkan untuk membantu Kementerian Pekerjaan Umum dalam rangka melaksanakan pengelolaan data sumber daya air sungai dan pantai di suatu wilayah sungai sesuai dengan aturan yang telah ditetapkan oleh regulasi yang ada, khususnya UU No. 7 Tahun 2004 Tentang SDA dan PP No. 42 Tahun 2008 Tentang Pengelolaan SDA.
\end{abstract}

Kata Kunci : Sistem Informasi Sungai dan Pantai, Database Sumberdaya Air, Daerah Aliran Sungai, Satuan Wilayah Sungai, DAS, SWS, River Basin.

\begin{abstract}
Development activity has been exploiting water resources (SDA) massively. Every year the number of critical watershed along with the increasing environmental degradation. Management of water resources are always either continued effort by the government to reduce the negative impact of environmental pollution. One way is to build an Information System Web-Based Coastal Rivers and can be used to determine the condition of water resources in the basin, so that the status of potential and water quality can be monitored at any time either by the government or the wider community and other civil society organizations. The information system Web-Based Coastal Rivers and can be realized by performing a data management of water resources in the basin structured through the development of Water Resource Database (DBSDA). Rivers and Coastal Information System (SISPA) Web-based was developed to assist the Ministry of Public Works in order to carry out the data management of water resources and coastal rivers in the basin in accordance with the rules established by the existing regulations, particularly the Law 7 Year 2004 on SDA and PP 42 Year 2008 on Management of Natural Resources.
\end{abstract}

Keywords : River and Coastal Information System, Water Resources Information SYstem, River Basin, River Basin Unit, DAS, SWS.

\section{PENDAHULUAN (UPPERCASE, LEFT, BOLD, FONT CALIBRI 10)}

Menurut data Departemen Dalam Negeri tahun 2004, Indonesia merupakan negara kepulauan dengan jumlah pulau terbanyak di dunia, yaitu sekitar 17.504 pulau yang tersebar dari Sabang sampai Merauke dengan memiliki cadangan air sebesar 3.221 milyar $\mathrm{m}^{3} /$ tahun dan menjadi negara terbesar ke 5 di dunia yang memiliki cadangan air 
terbesar. Dari cadangan ini hanya sebesar $21,46 \%$ atau sekitar 691,3 milyar $\mathrm{m}^{3} /$ tahun yang dapat dimanfaatkan. Sebanyak 141 milyar $\mathrm{m}^{3} /$ tahun dimanfaatkan untuk kebutuhan air irigasi, 6,4 milyar $\mathrm{m}^{3} /$ tahun dimanfaatkan untuk kebutuhan rumah tangga dan air perkotaan, serta sebanyak 27,7 milyar $\mathrm{m}^{3} /$ tahun dimanfaatkan untuk kebutuhan industri. Sisanya untuk keperluan lainya.

Isu dan permasalahan konservasi sumber daya air di Indonesia sangatlah kompleks dan sangat memerlukan penanganan yang serius. Beberapa permasalahan tersebut adalah sebagai berikut : Meluasnya lahan kritis, yaitu 13,1 juta Ha pada tahun 1992, dan saat ini mencapai lebih dari 18,5 juta Ha. Meningkatnya sebaran DAS kritis, yaitu 22 DAS pada tahun 1984, menjadi 39 DAS pada tahun 1992, dan menjadi 62 DAS pada tahun 2005. Tingginya laju sedimentasi pada waduk-waduk besar, yaitu $40-50 \%$ volume dead storage. Terjadinya degradasi dasar sungai akibat galian Golongan $\mathrm{C}$ tak berizin. Menurunnya daya dukung beberapa daerah tangkapan air yang berakibat pada turunnya keandalan debit sungai sebagai sumber air sebagian besar di (90\%) lahan irigasi.

Untuk mengelola cadangan sumberdaya air yang sangat besar dan mengendalikan permasalahan konservasi sumber daya air, pemerintah melalui Kementerian Pekerjaan Umum telah melakukan pengumpulan data sumberdaya air setiap tahunnya. Salah satunya adalah data potensi sungai dan pantai. Untuk itu perlu disusun sebuah sistem informasi yang mampu melakukan pengelolaan data potensi sumber daya air khususnya untuk pengelolaan data sungai dan pantai. Sistem informasi ini diharapkan mampu membantu balai-balai besar wilayah sungai di seluruh Indonesia untuk mengelola data sungai dan pantai di wilayah sungainya masing-masing.

Kegiatan ini bertujuan untuk merancang dan mengembangkan sistem informasi sungai dan pantai untuk pengelolaan data potensi sumberdaya air. Sedangkan sasaran kegiatan ini adalah terbentuknya rancangan dan prototipe aplikasi sistem informasi sungai dan pantai berbasis web yang dapat diakses secara online melalui jaringan internet.

Manfaat yang diharapkan dari pengembangan sistem informasi sungai dan pantai ini adalah : tersusunnya rancangan basis data sungai dan pantai, tersedianya sistem informasi yang dapat memberikan informasi potensi data sumber daya air khususnya sungai dan pantai, adanya efisiensi dan efektivitas pengelolaan data sumber daya air sungai dan pantai, serta terpantaunya pencatatan seluruh kegiatan manajemen pengairan di lingkungan balai besar wilayah sungai.

Lingkup kegiatan yang dilaksanakan untuk pengembangan sistem informasi sungai dan pantai adalah sebagai berikut : Identifikasi kebijakan nasional mengenai sumber daya air sungai dan pantai. identifikasi data sumberdaya air di wilayah sungai khususnya untuk sungai dan pantai, perancangan basis data sungai dan pantai, pengembangan aplikasi berbasis web sistem informasi sungai dan pantai untuk pengelolaan data inventarisasi sumberdaya air yang dapat dioperasikan dengan mudah.

\section{BAHASAN}

\subsection{Metodologi}

Metodologi pengembangan apliaksi web ini adalah Software Development Live Cycle (SLDC) yang artinya siklus hidup pengembangan software, yang memiliki tahapan sebagai berikut:

a. Tahapan analisa dan disain. Pada tahapan ini dilakukan analisa terhadap komponen sumber daya air sungai dan pantai yang ada dan merancang basis data sumber daya air.

b. Tahapan pengembangan sistem. Pada tahapan ini dilakukan pengembangan sistem software sistem informasi sungai dan pantai berbasis web.

c. Tahapan pengujian software. Pada tahapan ini dilakukan pengujian sistem software baik sistem databasenya maupun sistem user interfacenya untuk seluruh transaksi yang dihasilkan.

d. Tahapan evaluasi. Pada tahapan ini dilakukan evaluasi terhadap pelaksanaan keseluruhan kegiatan pengembangan sistem informasi sungai dan pantai.

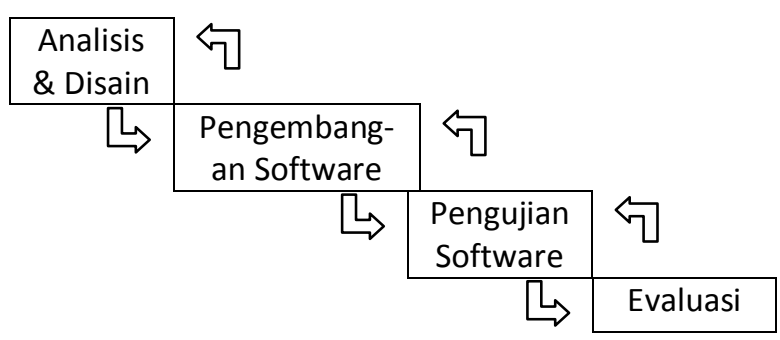

\section{Gambar 1. Metodologi Pengembangan Sistem}

Pada setiap tahapan metodologinya jika diperlukan perbaikan rancangan dan pengembangan dapat dilakukan secara iterasi atau dilakukan secara berulang-ulang antara tahapan yang satu ke tahapan yang lain sampai hasil yang diinginkan tercapai.

\subsection{DASAR HUKUM}

Untuk mengelola cadangan sumberdaya air yang sangat besar pemerintah Republik Indonesia telah mengeluarkan Undang-Undang No. 7 Tahun 2004 Tentang Sumber Daya Air dan Keputusan Presiden No 12 Tahun 2012 Tentang Penetapan Wilayah Sungai. Dalam peraturan ini wilayah sungai di Indonesia dibagi menjadi 131 Satuan Wilayah 
Sungai (SWS), yang terdiri dari beberapa kategori, yaitu :

- Wilayah sungai lintas negara sebanyak 5 SWS.

- Wilayah sungai lintas provinsi sebanyak 29 SWS.

- Wilayah sungai strategis nasional sebanyak 29 SWS.

- Wilayah sungai lintas kabupaten/kota sebanyak 53 SWS.

- Wilayah sungai dalam kabupaten/kota sebanyak 15 SWS.

Di dalam BAB VIII Pasal 65 Undang-Undang Sumber Daya Air disebutkan dalam ayat 1 bahwa "Untuk mendukung pengelolaan sumber daya air, pemerintah dan pemerintah daerah menyelenggarakan pengelolaan sistem informasi sumber daya air sesuai dengan kewenangannya". Dalam ayat 2 disebutkan bahwa "Informasi sumber daya air sebagaimana dimaksud pada ayat (1) meliputi informasi mengenai kondisi hidrologis, hidrometeorologis, hidrogeologis, kebijakan sumber daya air, prasarana sumber daya air, teknologi sumber daya air, lingkungan pada sumber daya air dan sekitarnya, serta kegiatan sosial ekonomi budaya masyarakat yang terkait dengan sumber daya air".

\subsection{Pembahasan}

\subsubsection{Disain database}

Disain database sungai dan pantai dihasilkan dari hasil analisa terhadap entitas komponen sumber daya air yang berada di wilayah sungai dan pantai. Entitas tersebut dikelompokkan ke dalam beberapa entitas sumber daya air yang kemudian setiap entitasnya menjadi tabel basis data sungai dan pantai. Database ini diharapkan dapat menjadi sistem inventarisasi aset sumberdaya air juga, sehingga potensi sumber daya air untuk sungai dan pantai dapat diperoleh dari rekap data yang ada.

Berikut ini adalah tabel database sungai dan pantai yang dikelompokkan ke dalam beberapa kategori sumber daya air, yaitu :

A. Kategori Data Sumber Daya Air

1. Wilayah Sungai

2. Daerah Aliran/Pengaliran Sungai

3. Sungai Induk

4. Anak Sungai

5. Danau

6. Waduk

7. Situ

8. Polder

9. Embung

10. Rawa

11. Pantai

12. Gununga Api

B. Kategori Data Prasarana Pengelolaan

1. Saluran

2. Sodetan (Short-cut, Coupure)
3. Sabo Dam

4. Dam Parit

5. Terowongan

6. Siphon

7. Ambal Dasar (Ground Sill, Bottom Controller)

8. Pintu Air

9. Rumah Pompa

10. Tanggul

11. Parapet

12. Pelindung Tebing (Revetment, Rip-rap)

13. Penguat Tebing (Turap, Retaining Wall)

14. Pengarah Aliran

C. Kategori Data Bangunan Pengelolaan

1. Tambak

2. Bendung

3. Bendungan

4. Irigasi Teknis

5. Irigasi Semi Teknis

6. Irigasi Non Teknis

7. Irigasi Air Tanah

8. Irigasi Tadah Hujan

9. Pengelolaan Air Baku

10. Pengendalian Banjir

11. Pengendalian Erosi dan Sedimentasi

12. Jetty / Tanggul Muara

13. Tanggul Laut

14. Kantong Lahar

15. Pengendalian Kualitas Air

D. Kategori Data Bangunan Pendukung Pengelolaan

1. Balai Besar Wilayah Sungai

2. Stasiun Pos Duga Air

3. Stasiun Hujan

4. Stasiun Klimatologi

5. Stasiun Pasang Surut Air Laut

Atribut informasi yang dihasilkan dari analisa lebih detail terhadap semua entitas sumber daya air ada sekitar 500 atribut informasi yang akan menjadi field masing-masing tabel data dalam database sungai dan pantai yang saling terhubung.

\subsubsection{Pengembangan Sistem}

Sistem Informasi Sungai dan Pantai terdiri dari beberapa komponen, yaitu : Server Web, Server Database, Database Sumber Daya Air (Tabel, Form, Report dan Mesin Pencari), dan Web Browser serta informasi berbasis web lainnya. Semuanya terinstalasi pada personal komputer berkonfigurasi server. Sistem Informasi Sungai dan Pantai yang dikembangkan serta komponen pendukung lainnya menggunakan teknologi berbasis open source software (OSS) atau perangkat lunak sumber terbuka yang tidak memerlukan lisensi seperti perangkat lunak kompersial lainnya. Fungsi dari masing-masing komponen pendukung sistem informasi ini adalah sebagai berikut : 
a. Web Server. Komponen ini yang menghubungkan komputer dengan pengguna di internet. Melalui web server ini semua transaksi akses data terhadap sebuah sistem informasi akan diterima dan diteruskan kepada program aplikasi berbasis web tersebut. Program web server juga tersedia dalam bentuk software berlisensi maupun open source, misalnya : MS Internet Information Service (IIS), Apache HTTP server, Cern HTTPD.

b. Database Server. Komponen ini yang akan mengelola data sumberdaya air baik yang diminta/ditelusuri maupun yang akan disimpan ke dalam media penyimpan. Database ini bekerja hanya jika ada permintaan akses data dari program aplikasi berbasis web yang khusus dibuat untuk mengakses database ini. Program database server juga tersedia dalam bentuk software berlisensi maupun open source, misalnya : MS Access, MS SQL Server,Oracle, MySQL, Postgress.

c. Development Tools. Komponen ini digunakan untuk membangun tampilan antar muka (user interface) database dan sistem informasi sumberdaya air. Teknik pengembangannya dapat menggunakan orientasi obyek (Object Orientation) dan penulisan kode program dalam bahasa pemrograman. Beberapa bahasa pemrograman untuk pengembangan aplikasi berbasis web adalah : HTML / PHP / ASP, Java Script / Java Applet.

d. Web Browser. Komponen ini digunakan untuk menampilkan aplikasi yang telah dikembangkan menggunakan basis web. Dengan menggunakan web browser ini pengguna tidak perlu menginstalasikan aplikasi database yang akan diakses ke dalam komputernya. Aplikasi database berada di server dan web browser berada di setiap komputer client. Web browser banyak tersedia dalam bentuk free open source, misalnya : Microsoft Internet Explorer, Mozilla Firefox, Opera, Netscape.

Spesifikasi minimal sistem komputer yang dibutuhkan untuk pengoperasian software Sistem Informasi Sungai dan Pantai adalah sebagai berikut :

$\begin{array}{ll}\text { A. Spesifikasi Hardware : } \\ \text { Processor } & : \text { Pentium IV } \\ \text { Memori } & : 512 \mathrm{MB} \\ \text { Cache } & : 512 \mathrm{~KB} \\ \text { Memori VGA } & : 32 \mathrm{MB} \\ \text { HDD } & : 40 \mathrm{~GB} \\ \text { Monitor } & : 17 " \\ \text { Minimal Resolusi } & : 1280 \times 1024\end{array}$

Media Backup : CDROM Writer

B. Kebutuhan Aplikasi Pendukung :

$\begin{array}{ll}\text { Sistem Operasi } & \text { : MS Windows 7/PC Unix } \\ \text { Server Aplikasi } & \text { : Xampp } \\ \text { Server Database } & \text { : MySQL } \\ \text { Server web } & \text { : Apache } \\ \text { Programming } & \text { : HTML, PHP, Java Script } \\ \text { Utilitas } & \text { : phpMyAdmin, DBRSE, MySQL } \\ & \text { Dumper } \\ \text { Web browser } & \text { : Firefox/Chrome }\end{array}$

Sistem Informasi Sungai dan Pantai dikembangkan berdasarkan kategori kelompok data sumber daya air yang ada dengan membangun setiap komponen sumber daya airnya ke dalam modulmodul aplikasi. Modul-modul ini merupakan user interface (antar muka) bagi pengguna yang dikembangkan multifungsi untuk penelusuran data sekaligus penyuntingan data sungai dan pantai. Pemanggilan modul aplikasi ini dilakukan menggunakan ikon-ikon yang mewakili aktifitas kegiatan pengelolaan sumber daya air, seperti gambar-gambar berikut :

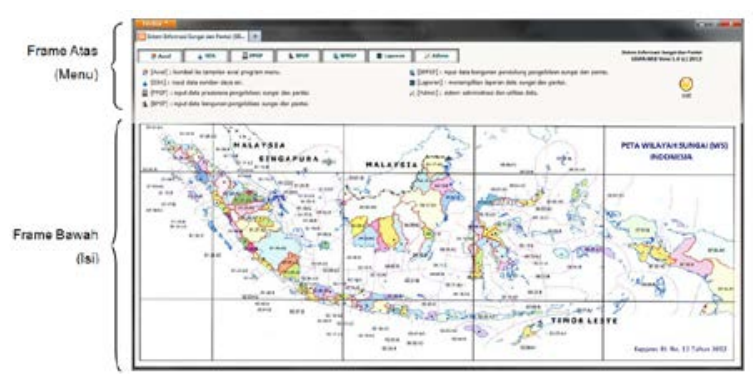

Gambar 1. Tampilan Menu [Awal] Software Aplikasi Web SISPA

Program Menu Utama yang dikembangkan digunakan untuk menintegrasikan penggunaan modul-modul obyek sumber daya air yang ada dalam sistem informasi ini. Program menu utama terdiri dari susunan beberapa tab control yang mewakili pengelompokkan obyek sumber daya air dan di dalamnya terdapat beberapa ikon yang mewakili masing-masing obyek sumber daya air, yaitu terdiri dari 7 Tab Control sebagai berikut:

1. Tab Control Awal, berfungsi untuk menampilkan kondisi awal aplikasi yang berisi penjelasan singkat masing-masing tab control lainnya.

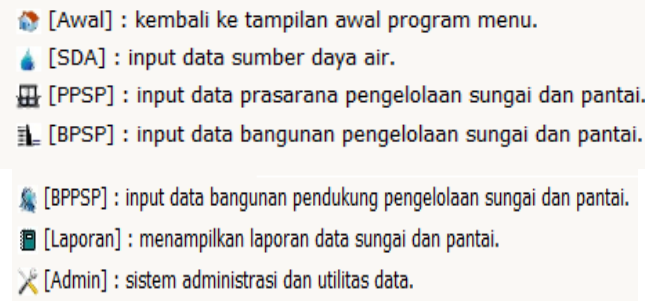


Gambar 2. Penjelasan Masing-Masing Tab Control

2. Tab Control SDA (Sumber Daya Air), berfungsi untuk menampilkan ikon-ikon yang mewakili kelompok modul dari obyek Sumber Daya Air.

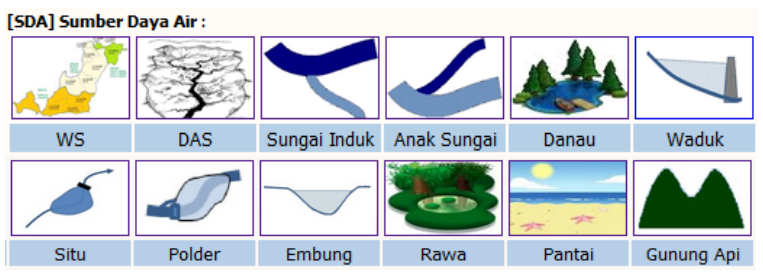

Gambar 3. Menu Ikon Sumber Daya Air

- Ikon WS, berfungsi untuk menampilkan modul Wilayah Sungai (WS) ke layar monitor.

- Ikon DAS, berfungsi untuk menampilkan modul Daerah Aliran/Pengaliran Sungai.

- Ikon Sungai Induk, untuk menampilkan modul Sungai Induk ke layar monitor.

- Ikon Anak Sungai, berfungsi untuk menampilkan modul Anak Sungai ke layar monitor.

- Ikon Danau, berfungsi untuk menampilkan modul Danau ke layar monitor.

- Ikon Waduk, berfungsi untuk menampilkan modul Waduk ke layar monitor.

- Ikon Situ, berfungsi untuk menampilkan modul Situ ke layar monitor.

- Ikon Polder, berfungsi untuk menampilkan modul Polder ke layar monitor.

- Ikon Embung, berfungsi untuk menampilkan modul Embung ke layar monitor.

- Ikon Rawa, berfungsi untuk menampilkan modul Rawa ke layar monitor.

- Ikon Pantai, berfungsi untuk menampilkan modul Pantai ke layar monitor.

- Ikon Gunung Api, berfungsi untuk menampilkan modul Gunung Api ke layar monitor.

3. Tab Control PPSP (Prasarana Pengelolaan Sungai dan Pantai), berfungsi untuk menampilkan ikon-ikon yang mewakili kelompok modul dari obyek Prasarana Pengelolaan Sungai dan Pantai.

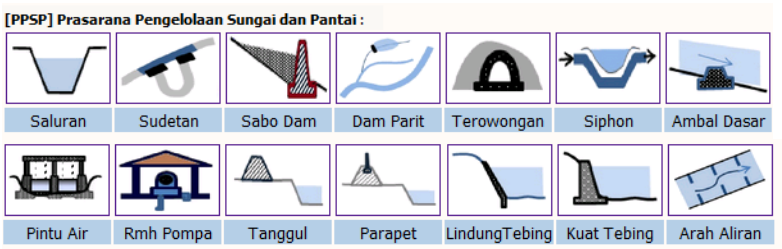

Gambar 4. Menu Ikon Prasarana Pengelolaan Sungai dan Pantai

- Ikon Saluran, berfungsi untuk menampilkan modul Saluran ke layar monitor.
- Ikon Sodetan, berfungsi untuk menampilkan modul Sodetan ke layar monitor.

- Ikon Sabo Dam, berfungsi untuk menampilkan modul Sabo Dam ke layar monitor.

- Ikon Dam Parit, berfungsi untuk menampilkan modul Dam Parit ke layar monitor.

- Ikon Terowongan, berfungsi untuk menampilkan modul Terowongan ke layar monitor.

- Ikon Siphon, berfungsi untuk menampilkan modul Siphon ke layar monitor.

- Ikon Ambal Dasar, berfungsi untuk menampilkan modul Ambal Dasar ke layar monitor.

- Ikon Pintu Air, berfungsi untuk menampilkan modul Pintu Air ke layar monitor.

- Ikon Rmh Pompa, berfungsi untuk menampilkan modul Rumah Pompa ke monitor.

- Ikon Tanggul, berfungsi untuk menampilkan modul Tanggul ke layar monitor.

- Ikon Parapet, berfungsi untuk menampilkan modul Parapet ke layar monitor.

- Ikon Lindung Tebing, untuk menampilkan modul Pelindung Tebing ke layar monitor.

- Ikon Kuat Tebing, untuk menampilkan modul Penguat Tebing ke layar monitor.

- Ikon Arah Aliran, untuk menampilkan modul Pengarah Aliran ke layar monitor.

4. Tab Control BPSP (Bangunan Pengelolaan Sungai dan Pantai), berfungsi untuk menampilkan ikon-ikon yang mewakili kelompok modul dari obyek Bangunan Pengelolaan Sungai dan Pantai.

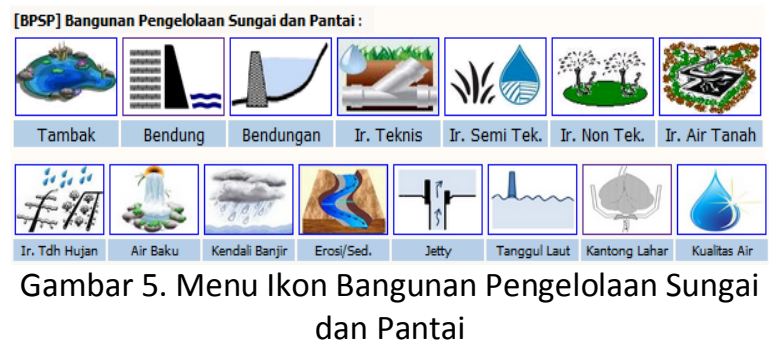

- Ikon Tambak, berfungsi untuk menampilkan modul Tambak ke layar monitor.

- Ikon Bendung, berfungsi untuk menampilkan modul Bendung ke layar monitor.

- Ikon Bendungan, berfungsi untuk menampilkan modul Bendungan ke layar monitor.

- Ikon Ir. Teknis, berfungsi untuk menampilkan modul Irigasi Teknis ke layar monitor.

- Ikon Ir. Semi Teknis untuk menampilkan modul Irigasi Semi Teknis ke layar monitor. 
- Ikon Ir. Non Teknis untuk menampilkan modul Irigasi Non Teknis ke layar monitor.

- Ikon Ir. Air Tanah untuk menampilkan modul Irigasi Air Tanah ke layar monitor.

- Ikon Ir. Tdh Hujan untuk menampilkan modul Tadah Hujan Teknis ke layar monitor.

- Ikon Air Baku, berfungsi untuk menampilkan modul Air Baku Teknis ke layar monitor.

- Ikon Kendali Banjir untuk menampilkan modul Bangunan Pengendali Banjir ke layar.

- Ikon Erosi/Sed menampilkan modul Bangunan Pengendali Erosi dan Sedimentasi.

- Ikon Jetty berfungsi untuk menampilkan modul Jetty/Tanggul Muara ke layar monitor.

- Ikon Tanggul Laut untuk menampilkan modul Tanggul Laut ke layar monitor.

- Ikon Kantong Lahar untuk menampilkan modul Kantong Lahar ke layar monitor.

- Ikon Kualitas Air untuk menampilkan modul Bangunan Pengenalian Kualitas Air.

5. Tab Control BPPSP (Bangunan Pendukung Pengelolaan Sungai dan Pantai), berfungsi untuk menampilkan ikon-ikon yang mewakili kelompok modul dari obyek Bangunan Pendukung Pengelolaan Sungai dan Pantai.

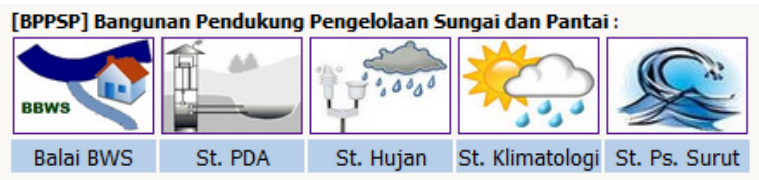

Gambar 6. Menu Ikon Bangunan Pendukung Pengelolaan Sungai dan Pantai

- Ikon Balai BWS untuk menampilkan modul Balai Besar Wilayah Sungai ke layar.

- Ikon St. PDA, berfungsi untuk menampilkan modul Stasiun Pos Duga Air ke layar.

- Ikon St. Hujan, berfungsi untuk menampilkan modul Stasiun Hujan ke layar monitor.

- Ikon St. Klimatologi untuk menampilkan modul Stasiun Klimatologi ke layar monitor.

- Ikon St. Ps. Surut untuk menampilkan modul Stasiun Pasang Surut Air Laut ke layar.

6. Tab Control Laporan, berfungsi untuk menampilkan ikon-ikon yang mewakili kelompok modul pelaporan data sungai dan pantai.

[Laporan] Menampilkan Laporan Data Sungai dan Pantai :

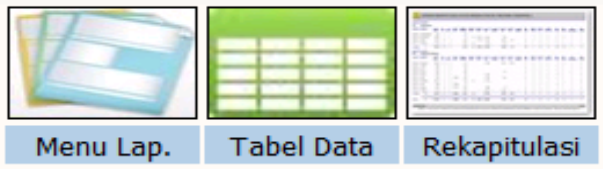

Gambar 7. Menu Ikon Laporan Data Sungai dan Pantai
- Ikon Menu Lap untuk menampilkan modul pelaporan data sungai dan pantai ke layar.

- Ikon Tabel Data untuk menampilkan modul tabel data sungai dan pantai ke layar.

- Ikon Rekapitulasi untuk menampilkan modul laporan rekapitulasi data sungai \& pantai.

7. Tab Control Admin, berfungsi untuk menampilkan ikon-ikon yang mewakili kelompok modul sistem administrasi dan utilitas data.

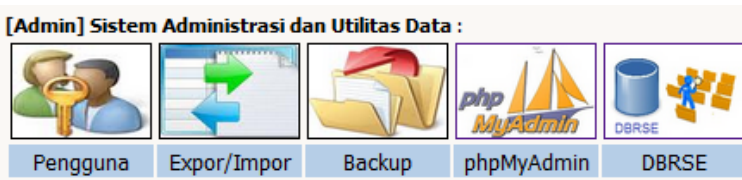

Gambar 8. Menu Ikon Sistem Administrasi dan Utilitas Data

- Ikon Pengguna untuk menampilkan modul pengguna aplikasi ini ke layar monitor.

- Ikon Expor/Impor untuk menampilkan modul utilitas expor/impor data sungai \& pantai.

- Ikon Backup untuk menampilkan modul backup database sumber daya air ke layar.

- Ikon phpMyAdmin, berfungsi untuk membuka utilitas database (untuk administrator)

- Ikon DBRSE, berfungsi untuk membuka utilitas penelusuran database.

Modul obyek sumber daya air dikembangkan secara terpisah, dimana satu obyek SDA dikembangkan ke dalam satu program modul. Untuk mengoperasikan masing-masing modul obyek sumber daya air disediakan beberapa menu dan ikon navigasi data. Gambar di bawah ini adalah tampilan menu dan ikon navigasi yang dibuat di dalam masing-masing modul SDA.

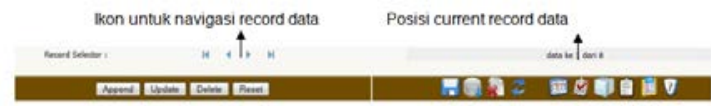

Gambar 9. Menu dan Ikon Navigasi Data

- Ikon naviasi record data digunakan untuk menampilkan pembacaan setiap record data ke layar monitor secara lengkap.

- Ikon First Record $\mathbb{V}$ untuk memanggil data pada posisi record data pertama.

- Ikon Previous Record untuk memanggil data pada posisi record data sebelumnya.

- Ikon Next Record untuk memanggil data pada posisi record data berikutnya.

- Ikon Last Record DI digunakan untuk memanggil data pada posisi record data terakhir. 
- Menu [Append] dan ikon Append Data digunakan untuk menambah dan menyimpan data ke dalam database.

- Menu [Update] dan ikon Update Data digunakan untuk menyimpan perubahan / update data ke dalam database.

- Menu [Delete] dan ikon Delete Data $x$ untuk menghapus data dari dalam database.

- Menu [Reset] untuk menghapus dan membersihkan tampilan data dari layar monitor.

- Ikon Reload Data $\approx$ untuk memanggil kembali data dan menampilkannya ke layar.

- Ikon Tabel Data untuk menampilkan laporan dalam bentuk tabel data ke layar.

- Ikon Laporan Satuan Data digunakan untuk menampilkan laporan satuan data pada posisi current record data ke layar monitor.

- Ikon Laporan Seluruh Data digunakan untuk menampilkan laporan satuan data pada seluruh record data ke layar monitor.

- Ikon Laporan Ringkas $\mathrm{G}$ untuk menampilkan laporan ringkat data ke layar monitor.

- Ikon Laporan Rinci 圈 untuk menampilkan laporan ringkat data ke layar monitor.

- Ikon Petunjuk Pengisian digunakan untuk menampilkan petunjuk pengisian form input data ke layar monitor.

\subsubsection{Pengujian Sistem}

Pengujian sistem perangkat lunak (software testing) dilakukan beberapa kali per modul secara bertahap. Hal-hal yang diuji meliputi kekonsistenan tampilan layar modul, tata bahasa dan kosa kata yang digunakan, proses input dan retrieve data pada masing-masing kolom, fungsi masing-masing ikon di dalam setiap modul, dan proses transaksi data dari aplikasi program web broser ke database server. Pengujian dilakukan oleh beberapa software tester baik yang memiliki latar belakang teknologi informasi dan komputer maupun latar belakang bidang lain. Kriteria keberhasilkan pengujian sistem software ini adalah makin banyak kesalahan / error ditemukan semakin berhasil software tester itu bekerja.

Hasil pengujian ini dijadikan pedoman untuk melakukan revisi dan update yang diperlukan untuk penyempurnaan setiap modul-modul sumber daya air yang dihasilkan dalam proses pengembangan secara bertahap. Ada kurang lebih 46 modul aplikasi yang sudah dihasilkan dan dilakukan pengujiannya. Selain pengujian terhadap modul-modul aplikasi sistem informasi sungai dan pantai, pengujian dilakukan juga terhadap sistem dan prosedur instalasi serta konfigurasi yang telah disiapkan dalam penyusunan setup wizard untuk aplikasi sistem informasi sungai dan pantai. Pada tahap awal pengujian dilakukan secara offline secara bertahap dan dilanjutkan juga secara online secara bertahap pula.

\subsubsection{Evaluasi Kegiatan}

Evaluasi terhadap progres pengembangan dilakukan beberapa kali antara tim pengembang dari Pusat Teknologi Lingkungan, BPP Teknologi dan tim evaluator dari Direktorat Jenderal Kementerian Pekerjaan Umum. Masukan terhadap penyempurnaan baik bentuk tampilan maupun proses kerja dan transaksi data sistem informasi ini telah diperoleh selama proses evaluasi berjalan.

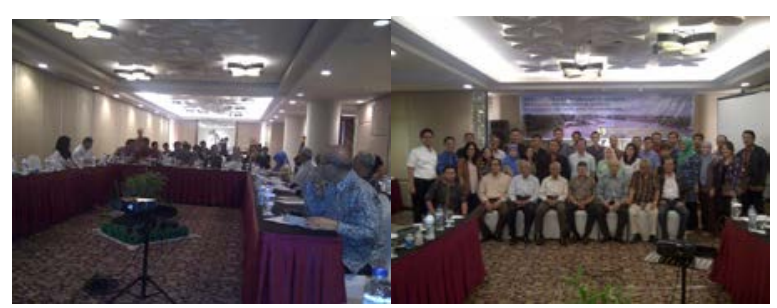

Gambar 9. Foto Kegiatan Evaluasi

\subsubsection{Hasil Kegiatan}

Kegiatan pengembangan sistem informasi sungai dan pantai menghasilkan beberapa keluaran, yaitu :

- Prototipe aplikasi sistem informasi untuk pengelolaan data sungai dan pantai yang dikelompokkan dalam empat kategori data sumber daya air.

- 46 modul aplikasi pengelolaan data sungai dan pantai berikut petunjuk penggunaannya yang dapat diakses langsung secara online.

- Beberapa modul untuk pelaporan data (ringkas, singkat, dan lengkap) yang dapat dicetak dalam bentuk PDF atau dikirimkan melalui email serta beberapa modul untuk manajemen databasenya.

- Buku petunjuk operasional piranti lunak sistem informasi sungai dan pantai dalam bentuk elektronik maupun cetak.

- Buku panduan pengelolaan data sungai dan pantai.

Gambar di bawah ini adalah salah satu tampilan modul untuk pengelolaan data sungai dan pantai modul daerah aliran / pengaliran sungai.

\section{KESIMPULAN (UPPERCASE, LEFT, BOLD, FONT CALIBRI 10)}

Beberapa hal yang dapat disimpulkan mengenai kegiatan pengembangan sistem informasi sungai dan pantai adalah sebagai berikut : 
- Sistem database dan aplikasi sistem informasi dikembangkan menggunakan teknologi open source, sehingga dapat meminimasi biaya pengadaan perangkat lunak yang tidak semahal perangkat lunak berlisensi lainnya.

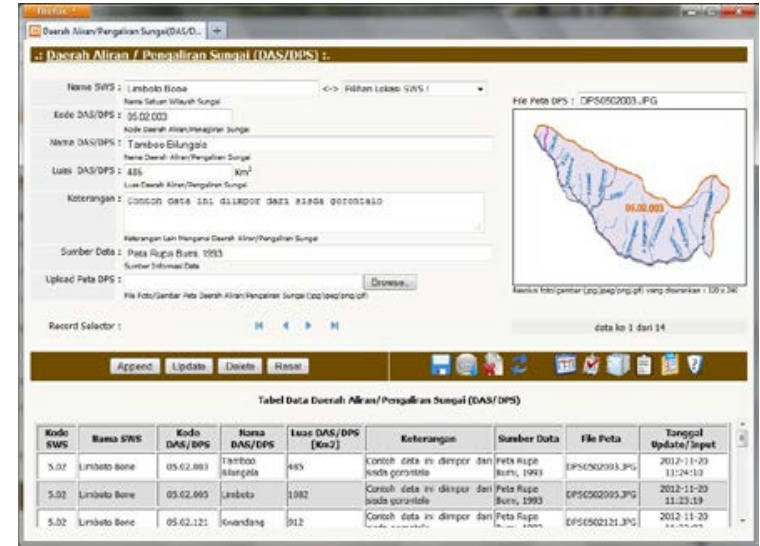

Gambar 10. Aplikasi Web Daerah Aliran / Pengaliran Sungai

- Dari delapan target sistem informasi yang disebutkan dalam UU No. 7 Tahun 2004 (hidrologis, hidrometeorologis, hidrogeologis, kebijakan SDA, prasarana SDA, teknologi SDA, lingkungan SDA, dan sosial ekonomi budaya masyarakat yang terkait dengan SDA), sistem informasi sungai dan pantai hanya mencakup target pengelolaan data prasarana sumber daya air.

- Atribut informasi yang ditampilkan dalam setiap modul sumber daya air mencerminkan potensi sumber daya air tersebut yang laporannya seketika itu juga dapat dibuat secara otomatis oleh sistem komputer.

- Sistem informasi sungai dan pantai yang telah dikembangkan saat ini sudah dapat diakses secara online melalui jaringan internet.

\section{DAFTAR PUSTAKA}

- Nama, tahun, Judul, Penerbit, Vol (No), hal. (perhatikan cara saat menulis nama ke-1 dan ke2 pada contoh dibawah ini).

- Garno, Y.S. 2000, Uji BOD, Indikator kekuatan limbah yang masih bermasalah, J. Tek.Ling, P3TLBPPT. 1(1) 96-100.

- Komarawidjaja W. dan Y.S. Garno 2000: Uji Kualitatif Potensi Mikroba Penitrifikasi Lingkungan Perairan Tambak Udang di Tagerang dan Jepara. JSTI- BPPT. 2(4): 108-11

- Buku Kegiatan 2010 2011 Sumber Daya Air, Direktorat Jendral Sumber Daya Air, Kementerian Pekerjaan Umum, 2011
- Business information systems: analysis, design and practice. 5th ed. Harlow: Prentice Ha, Curtis, G. \& Cobham, D., 2005

- Keputusan Presiden No 12 Tahun 2012 Tentang Penetapan Wilayah Sungai, Sekretariat Kabinet RI, 2012

- Undang-Undang no. 7 Tahun 2004 Tentang Sumber Daya Air, Sekretaris Negara RI, 2004

- Universal Network Server, Heru Dwi Wahjono, Meridian University College, 2003

- Buku Petunjuk Operasional Piranti Lunak Sistem Informasi Sungai dan Pantai Versi 1.0, Heru Dwi Wahjono, 2013 